\title{
Developing a national minimum data set for hospital information systems in the Islamic Republic of Iran
}

\author{
Zahra Rampisheh, ${ }^{1}$ Mohammad Esmaeil Kameli, ${ }^{2}$ Javad Zarei, ${ }^{3}$ Akram Vahedi Barzaki, ${ }^{4}$ Marziyhe Meraji ${ }^{5}$ and Ali Mohammadi ${ }^{6}$
}

${ }^{1}$ Preventive Medicine and Public Health Research Center, Department of Community Medicine, School of Medicine, Iran University of Medical Sciences, Tehran, Islamic Republic of Iran. ${ }^{2}$ Department of Community Medicine, School of Medicine, Iran University of Medical Sciences, Tehran, Islamic Republic of Iran. ${ }^{3}$ Department of Health Information Technology, School of Allied Medical Sciences, Ahvaz Jundishapur University of Medical Sciences, Ahvaz, Islamic Republic of Iran. ${ }^{4}$ Health Information Management Research Center, Kashan University of Medical Sciences, Kashan, Islamic Republic of Iran. ${ }^{5}$ Department of Medical Records and Health Information Technology, Faculty of Paramedical Sciences, Mashhad University of Medical Sciences, Mashhad, Islamic Republic of Iran. ${ }^{6}$ Department of Health Information Technology, School of Paramedicine, Kermanshah University of Medical Sciences, Kermanshah, Islamic Republic of Iran. (Correspondence to: Ali Mohammadi:a.mohammadi@kums.ac.ir).

\begin{abstract}
Background: Standardized data collection supports disease information management and leads to better quality of care. The Islamic Republic of Iran lacks a standard data set for data collection in hospitals.

Aims: The aim of this study was to design a minimum data set for hospital information systems in the Islamic Republic of Iran.

Methods: This study was conducted in 2015. Data sets of other countries, hospital records, hospital information systems and electronic health record systems in the Islamic Republic of Iran were reviewed for data elements for the minimum data set. Data elements were collected using a data extraction form and were categorized into similar classes, which were divided into administrative and clinical sections. The list of data elements was reviewed by experts in technical offices of the Iranian Ministry of Health and Medical Education, and a minimum data set was drawn up.

Results: There were nine and 18 data classes in the administrative and clinical sections with a total of 166 and 684 data elements respectively. After review by the expert panel, 159 administrative and 621 clinical data elements were retained as the minimum data set for the Iranian hospital information system.
\end{abstract}

Conclusion: Our dataset can be used by the Iranian health ministry, hospital information system companies and health surveillance centres for more efficient management of health data.

Keywords: Minimum data set, hospital information systems, health records, Iran

Citation: Rampisheh Z; Kameli M; Zarei J; Vahedi Barzaki A; Meraji M; Mohammadi A. Developing a national minimum data set for hospital information systems in the Islamic Republic of Iran. East Mediterr Health J. 2020;26(4):400-409. https://doi.org/10.26719/emhj.19.046

Received: 25/11/16; accepted: 26/07/18

Copyright ( ) World Health Organization (WHO) 2020. Open Access. Some rights reserved. This work is available under the CC BY-NC-SA 3.0 IGO license (https://creativecommons.org/licenses/by-nc-sa/3.o/igo).

\section{Introduction}

Data quality in a hospital information system plays an important role in health policy-making. Low quality of the data increases the rate of medical errors and lowers the quality of care (1). Designing a structure for standardized data collection supports disease information management and leads to better quality of care (2). Standard health care data usually indicate minimum data elements that should be collected (3).

A minimum data set is a standard data collection tool (4). In each area, the minimum data set contains many data elements for demographic data, health and treatment status, reimbursement resources, and patient transfer location (5). The main objective of the minimum data set is to build a national database that can serve as an information management source to equip decision-makers and policy-makers with accurate and up-to-date information (6). The minimum data set of each area strengthens the relationship between the studies conducted and extraction of research results, improves plans, strategies and policies, and provides the opportunity for equity in the health system (7).

In the health care system, data sets identify data elements that should be collected for each patient and provide definitions for each element based on standards. Data comparison is used for different purposes including external accreditation, evaluation of internal performance, and research and statistical studies. Therefore, it is important to determine standard data sets to manage the clinical performance of health organizations in every country (8).

Although minimum data sets are specific to each country, they should be able to allow data comparison at an international level. In this regard, many countries have developed national general or specialized minimum data sets for their health information systems (9). These include: Qatar (2014) (10), Denmark (1987), Germany (MDIM 1995), United Kingdom of Great Britain and Northern Ireland (NHS-MDS, 1993), the Netherlands (1997), Australia (1995) (11), Canada (1998) (12), New Zealand (1992) (13) and the United States of America (1974) (14).

In the Islamic Republic of Iran, the content of hospital 
records, electronic health record systems (Samaneh Parvande Electronic Salamat [SEPAS] established by the Iranian Ministry of Health for data collection), and hospital information systems vary and the data elements of these systems are often incompatible because of the lack of any minimum data set. Collection of standard data and maximizing their quality in the Islamic Republic of Iran requires the development of a minimum data set for hospital information systems. Therefore, in view of the lack of a standard data set in the country, this study was conducted to design a minimum data set to be used in hospital information systems.

\section{Methods}

This descriptive cross-sectional study was conducted in 2015. The data were collected from SEPAS, hospital information system documents of companies approved by the Iranian Ministry of Health and Medical Education, and inpatient records used in the Islamic Republic of Iran. Moreover, a review of the literature was done to find relevant resources, including documents, reports, guidelines and websites related to data elements of hospital, disease, administrative, equipment and medical intervention information systems by searching the Internet and print material.

The resources retrieved from the Internet search were selected based on the criteria in Table 1 and evaluated until saturation was achieved. The SEPAS documents were similar and data elements of the records were standard; therefore, the data elements in the SEPAS system and one of the records were evaluated. In addition, the data elements of the documents of 26 hospital information system companies approved by the Ministry of Health and Medical Education were evaluated.

A data extraction sheet was used for data collection. The data elements retrieved from the Internet, SEPAS system, hospital information system companies and hospital records were extracted separately and collected in four separate files: 1) Iranian and foreign studies as electronic and print material, 2) SEPAS system documents, 3) hospital information system documents and 4) medical records. The data elements retrieved from each source were categorized based on similar classes and subjects, and a complete file was created by combining all four files. The new file was categorized into administrative and clinical sections and each section was classified into different data classes.

Classification of data elements into administrative and clinical sections and their subclasses was done according to information management standards: the classification proposed by American National Standards Institute, American Society for Testing and Materials standards for Core Health Data Elements, reference books, classifications found in retrieved studies $(4,15,16)$, hospital records, hospital information system and SEPAS system. The views of the Information and Statistics Management Office of Ministry of Health and Medical Education were also considered.

For each class, the data elements of different resources (retrieved from, e.g. the Internet, health information system documents and SEPAS) were reviewed. Among common data elements, those with a more complete and comprehensive definition, format, domain, justification, code and source were included in the class. All uncommon data elements were also included. A Farsi or English title and definition was provided for the elements that only appeared in English or Farsi texts; in other words, all listed data elements had English and Farsi titles and a definition in Farsi.

The data elements for each data class were included in a checklist. The content validity of the checklist was assessed by 10 experts of the Ministry of Health and Medical Education technical offices, including four health information management experts, four physicians and two information technology experts. They were asked accept or reject each data element for inclusion in the hospital information system.

\begin{tabular}{|c|c|}
\hline Sites, criteria, strategy & Descriptions, characteristics \\
\hline Search engines & Yahoo, Google, Google Scholar \\
\hline Websites & World Health Organization, \\
\hline Databases & $\begin{array}{l}\text { PubMed, Web of Science, Scopus, EMBASE, IEEE (https://www.ieee. } \\
\text { org/publications/periodicals.html) Cochrane, SID (https://www.sid.ir/fa/ } \\
\text { journal/), Magiran, IranMedex, Civilica, Irandoc (up to September 2015) }\end{array}$ \\
\hline \multirow[t]{2}{*}{ Inclusion criteria } & Literature in English and Farsi \\
\hline & $\begin{array}{l}\text { Papers, annual reports, reports, guidelines and peer-reviewed research } \\
\text { published up to September } 2015 \text { from valid sources, with full text, a clearly } \\
\text { stated purpose, and keywords in the title or abstract. }\end{array}$ \\
\hline Exclusion criteria & $\begin{array}{l}\text { Non-peer-reviewed papers, reports and forms retrieved from personal blogs } \\
\text { and abstracts with no accessible full text. }\end{array}$ \\
\hline Search terms & $\begin{array}{l}\text { "Patient minimum data set", "Patient data element", "Hospital information } \\
\text { system" And "Data element", "Hospital Information system" And "Minimum } \\
\text { data set", "Health information system" And "Minimum data set", "Hospital } \\
\text { information database" }\end{array}$ \\
\hline
\end{tabular}




\begin{tabular}{|c|c|c|}
\hline & Data classes & Department/Office/Centre of the Ministry of Health and Medical Education \\
\hline \multirow{9}{*}{ 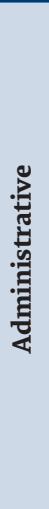 } & Demographic & \multirow{7}{*}{$\begin{array}{l}\text { Hospital information and statistics management office and Hospital management and } \\
\text { clinical excellence department }\end{array}$} \\
\hline & Admission & \\
\hline & Legal & \\
\hline & Discharge & \\
\hline & Personnel identifier of care provider & \\
\hline & Organization identifier & \\
\hline & Geographic & \\
\hline & Incident & Medical emergency management centre \\
\hline & Financing & $\begin{array}{l}\text { Tariff Office - Health technology assessment, standardization and tariff department, } \\
\text { Supreme Council for income distribution, and Economic planning and health insurance } \\
\text { group }\end{array}$ \\
\hline \multirow{18}{*}{ שֶّ } & Pre-hospital emergency & Medical emergency management centre \\
\hline & Hospital emergency & \\
\hline & Diagnosis & \multirow{8}{*}{$\begin{array}{l}\text { Five physicians in total in: Hospital information and statistics management office - } \\
\text { Curative resource management office - Hospital management and clinical excellence } \\
\text { department }\end{array}$} \\
\hline & Diagnostic/therapeutic procedure & \\
\hline & Orders & \\
\hline & Medical imaging & \\
\hline & Follow up & \\
\hline & History and review of patient body system & \\
\hline & Consultation & \\
\hline & Anaesthesia & \\
\hline & Laboratory & \multirow[t]{2}{*}{ Health reference laboratory } \\
\hline & Blood products & \\
\hline & Medicine & Food and drug administration \\
\hline & Medical prosthetics & Rehabilitation medicine specialist \\
\hline & Discharge status & \multirow{2}{*}{$\begin{array}{l}\text { Hospital information and statistics management office and Hospital management and } \\
\text { clinical excellence department }\end{array}$} \\
\hline & Transfer & \\
\hline & Nursing & Nursing office \\
\hline & Death & Network management centre \\
\hline
\end{tabular}

The checklist, together with an official letter from the Information and Statistics Management Office of the Ministry of Health and Medical Education, was sent to specialized technical offices and board bureaus and centres (specialized technical offices such as nursing, anaesthesia, laboratory), and the experts were asked to accept or reject the data elements that related to special fields (Table 2). The panel was selected purposively through convenience sampling and consisted of 22 experts working in eight different specialized technical offices and board bureaus and centres of the Ministry of Health and Medical Education, three physicians and three health information managers.

The data elements agreed upon by the experts of the technical offices, and board bureaus and centres of the Ministry of Health and Medical Education were returned to the Statistics and Information Management Office in an official letter.

\section{Results}

The national minimum data set for the Iranian hospital information system had an administrative section and a clinical section with nine and 18 data classes respectively. A total of 166 data elements were collected for the administrative section and 684 for the clinical section. These data elements decreased to 159 for the administrative section and 621 for the clinical section after review by the technical offices, board members, Ministry of Health and Medical Education deputy offices and specialized centres (Table 3).

The demographic class of the administrative section had the highest number of data elements $(n=51)$. In this class, three data elements (mother's first name, mother's family name and distance from home to hospital) were not agreed upon. The data elements of this class relate to identification number, nationality, and religious and social characteristics of the patient. The class of admission 


\begin{tabular}{|c|c|c|c|c|}
\hline & Data classes & No. of data elements & Accepted & Rejected \\
\hline \multirow{10}{*}{ 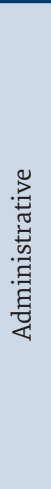 } & Demographic & 51 & 48 & 3 \\
\hline & Admission & 20 & 20 & 0 \\
\hline & Incident & 20 & 17 & 3 \\
\hline & Legal & 9 & 9 & 0 \\
\hline & Discharge & 10 & 10 & 0 \\
\hline & Financing & 25 & 25 & 0 \\
\hline & Personnel identifier & 7 & 6 & 1 \\
\hline & Organization identifier & 16 & 16 & 0 \\
\hline & Geographic & 8 & 8 & 0 \\
\hline & Total & 166 & 159 & 7 \\
\hline \multirow{19}{*}{ 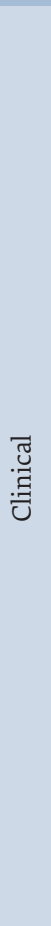 } & Diagnosis & 101 & 100 & 1 \\
\hline & Pre-hospital emergency & 82 & 40 & 42 \\
\hline & Hospital emergency & 110 & 104 & 6 \\
\hline & Diagnostic/therapeutic procedure & 78 & 78 & 0 \\
\hline & Orders & 17 & 17 & 0 \\
\hline & Medical imaging & 22 & 22 & 0 \\
\hline & Laboratory & 13 & 13 & 0 \\
\hline & Medicines & 36 & 34 & 2 \\
\hline & Medical prosthetics & 15 & 15 & 0 \\
\hline & Blood products & 10 & 10 & 0 \\
\hline & Discharge status & 10 & 10 & 0 \\
\hline & Transfer & 28 & 28 & 0 \\
\hline & Follow up & 8 & 8 & 0 \\
\hline & System history and review & 21 & 21 & 0 \\
\hline & Nursing & 58 & 48 & 10 \\
\hline & Consultation & 11 & 11 & 0 \\
\hline & Death & 34 & 34 & 0 \\
\hline & Anaesthesia & 30 & 28 & 2 \\
\hline & Total & 684 & 621 & 63 \\
\hline
\end{tabular}

had 20 data elements that were all agreed upon. This class includes admission information, such as the date, time, ward, room, and admission number. The class of incident also had 20 data elements, three of which were rejected, namely other participants at the accident scene, accident mechanism and the object or vehicle causing the accident. The data elements of this class relate to the date, time and location of the accident. All proposed data elements in legal, discharge, financing, organization identifier and geographic classes were accepted. In the class of personnel identifier, the data element of full name of the person providing services for the patient was rejected. Table 4 gives examples of the data elements for each data class in the administrative section.

In the clinical section, some data elements in the classes of diagnosis, pre-hospital and hospital emergency, medicines, nursing, and anaesthesia were not agreed upon. The highest disagreement was related to pre- hospital emergency data elements.

The first data class of the clinical section was diagnosis which had 101 data elements; of these only one was rejected: type of activity during the accident. The data elements of diagnosis include: main complaint; primary, during-treatment and final diagnosis; pre- and post-operative diagnosis; and International Classification of Diseases (ICD) codes (17).

The second class was pre-hospital emergency. The Medical Emergency Management Centre of the Ministry of Health and Medical Education rejected 42 out of 82 data elements in this class. The data elements of this class include dispatch date and time, type of transfer, and prehospital emergency procedures. The data class of hospital emergency had the highest number of clinical data elements $(n=110)$, of which 104 were agreed upon. The following data elements were rejected: medical facilities provided for the patient, level of specialized services of 
the emergency department, role of service provider, and consultant identifier. In the medicines class, the data elements on current dose and dose unit were rejected. In the anaesthesia class, post-operative pain management methods and hypertension following the use of preanaesthetic drugs were the two data elements that were rejected. In the nursing data class, no consensus was reached on the data elements: type of care, duration of admission to the intensive care unit, drug code, drug permission and treating physician. All the data elements of the other classes in the clinical section were accepted by the experts. Table 5 gives examples of the data elements for each data class in the clinical section.

\section{Discussion}

The proposed minimum data set of the Iranian hospital information system has administrative and clinical sections. Some specialized publications $(4,15)$ and studies on specialized minimum data sets have also used this classification $(18,19)$.

Administrative data are used for patient registration, medical centre identification, insurance and reimbursement (16), medical research, outcome evaluation and administrative reports (20). In this study, the administrative data were categorized into nine different data classes. They were are more comprehensive than similar hospital minimum data sets, such as those of Qatar (10), Australia (11), New Zealand (13) and the United States (14) and have more data elements, especially in the legal, incident and geographic data classes. The first class in this section is demographics. A number of other studies have considered this class as well (2,3,19,21-23).

Demographic data elements differ between those we propose, and the data elements currently used in Iranian hospital records and the data elements of other national data sets (24), and some essential data elements are needed in order to have comprehensive data. Another difference is the data elements between our set and other data sets relates to ethnicity and race. They are not included in our proposed demographic data set because they are not much needed in the Islamic Republic of Iran due to the racial and ethnic composition of the Iranian population. However, these data elements are used in most minimum data sets in countries with ethnic and migratory populations such as the United States $(14,25,26)$.

In the class of admission, some data elements related to patient admission to the medical centre, such as the date and time of admission, ward, room and bed number, and transferring hospital or centre, were proposed. Most of these data elements are similar to data elements for admission in other studies in the Islamic Republic of Iran $(18,21)$ and the minimum data sets of other countries $(10,13,25,27)$.

As for the class of incident, in order to assist incident registration, some data elements related to the person's activity during the incident and the incident location, mechanism, and intention (e.g. intention to cause injury) were proposed. Recording these data might help implement the system of International Classification of
External Causes of Injury (ICECI) (28). Moreover, these data are among the main data of the minimum data set for traffic incidents and injuries $(29,30)$. However, the proposed data set for the class of incident contained fewer data elements compared with specialized data sets for injuries such as the IDB-JAMIE minimum data set (31).

In the minimum data set designed for the Iranian hospital information system, in order to record data elements on informed consent and informing of legal authorities, the class of legal data was proposed. This class has also been considered in an minimum data set for orthopaedic injuries (18). Most data elements in this class do not appear in other minimum data sets $(10,14,25,26,31)$.

Type of insurance coverage, costs and method of payment for care received are data elements included in the class of financing. Final diagnosis and disease code are also included in this class in order to support a prospective payment system in the hospital. Recording these data has an important role in implementing diagnosis-related groups in Iranian hospitals (32). These data are similar to the financial data elements in most minimum data sets in other countries $(10,14,24)$.

In the class of organization identifier, some data elements such as institute name, identity, and organizational affiliation are similar to the data determined for the service-providing organization in other studies $(2,18,19,33)$ and minimum data sets in other countries $(10,24,25,27)$. However, the data elements of longitude and latitude coordinates to determine the exact location of the accident, website and email address of the health centre were also proposed for our data set. The longitude and latitude coordinates are also recorded in emergency-related data sets in many countries and in traffic incidents in the Islamic Republic of Iran $(12,30)$. Recording these data elements helps to study planning, accessing and distributing of health services based on geographic information systems (34). This data element was proposed in view of the importance of hospital websites in assisting the delivery of health services to patients and its role in the future (35).

In the class of personnel identifier, data elements related to identification of the health staff providing the care, including the first and last name, identity, role, academic qualification, and electronic signature, were considered. The class of geographic data elements was proposed to record accurate location data about the patient's home according to geographical divisions of the country. This was done because, at the time of the study, one of the concerns of the Iranian health ministry was to provide data to accurately define patients' locations in order to determine the level of access to services and assist in the fair distribution of health services, and to determine the prevalence of diseases.

The proposed clinical section had 18 data classes. Compared with similar minimum data sets in other countries $(10,14,24,27)$, our proposed clinical data set has more data elements. We tried to include as many clinical data elements of the patient's medical record as possible. 


\begin{tabular}{|c|c|}
\hline Data class & Data elements \\
\hline Demographic & $\begin{array}{l}\text { Patient's: National identity number, first/last/nick name and middle name, father's name, sex, date of } \\
\text { birth, religion, employment status, telephone number, mobile phone number, email address }\end{array}$ \\
\hline Admission & Type of entry, type of admission, admission date/hour, admission ward, room, bed number \\
\hline Incident & $\begin{array}{l}\text { Date/hour of incident, address where incident occurred, ICD-10 code for place of injury, longitude and } \\
\text { latitude coordinates, site of injury, nature of injury, final outcome }\end{array}$ \\
\hline Legal & $\begin{array}{l}\text { Reported to the police, advance health care directives, informed consent, type of informed consent, } \\
\text { informed consent date, witness first name, witness last name }\end{array}$ \\
\hline Discharge & Discharge date/hour, ward, patient discharge status, discharge type, length of stay, discharging physician \\
\hline Financing & $\begin{array}{l}\text { Insurance organization, insurance fund, other insurance organization, complementary insurance, } \\
\text { insurance serial number, insurance expiry date, name of service provided, service code, service unit }\end{array}$ \\
\hline Personnel identifier & $\begin{array}{l}\text { Health care provider - first name, health care provider - last name health care provider - ID, health care } \\
\text { provider - role, health care provider - specialty }\end{array}$ \\
\hline Organization identifier & $\begin{array}{l}\text { Health care centre name, health care centre type, health care centre ID, longitude/latitude coordinates, } \\
\text { health care centre affiliation }\end{array}$ \\
\hline Geographic & Patient location - geographic position, country, city, province, district, rural area, town, village \\
\hline
\end{tabular}

Diagnosis was the first class of the clinical section with 101 data elements. This class includes different diagnoses, their codes and disease signs. The ICD codes of different diseases are an important data element in this class which have also been considered in many minimum data sets $(18,19,21,27,33)$.

The class of pre-hospital emergency data rejected by the experts related to the characteristics of the vehicle for patient transfer and the transfer method. The aim of this class is to record the patient transfer method, procedures performed on the patient, information of the dispatching unit, and date and time of the contact and dispatch.

The class of hospital emergency data includes information on the emergency department, diagnoses, date and time of the procedures and the patient's status when emergency procedures had ended. This class has the highest number of data elements because of the wide range of emergency data in some of the data sets we evaluated $(11,12)$ and the importance of these data in hospital emergency information systems (36). The class of diagnostic/therapeutic procedures has 78 data elements which fully describe the diagnostic and therapeutic procedures performed on the patient. These data elements are related to the type, method, date and time of procedures (both start and end), and the ICD-9-CM codes for procedures. Some of these data elements have been mentioned in most studies on minimum data sets $(18,19,21,33)$. The data elements for procedures, especially surgical interventions, are among the most widely used data elements in clinical follow up (37). The class of orders has 17 data elements which aim to support the recording of details of the orders of medical staff, especially the treating physician.

The class of history data and systems evaluation has 21 data elements related to the personal and family history of the patient and evaluation of different organs. Some other studies have also considered this class under other names such as history (21), patient status evaluation (3) or physical examination and injury report (38).
In the class of nursing, some data elements such as interventions performed by nurses, nurses' evaluation at admission, laboratory tests and imaging studies, were rejected by the experts because they were included in other classes (laboratory and medical imaging). Some of these data elements are in line with the data proposed in another study (39).

Two data classes - medical imaging and laboratory - are proposed for paraclinical data. The data elements of medical imaging includes the type of radiography, technique, code, anatomical site, radiologist's name and interpretation. These data were proposed in another study which also had other elements (21). The laboratory data class includes the test name, test group, test code, number of tests and test results. Some other studies have included most of these data $(18,19,33)$.

A separate class with 34 data elements is proposed for the medicines administered, including the name, code, administration route and dose. A number of Iranian studies on minimum data sets have also considered a separate class for drugs $(2,3,18,19,38)$, indicating the importance of drug data. The anaesthesia data elements include the time of starting and ending anaesthesia and duration of anaesthesia, drugs used for anaesthesia, type of anaesthesia (e.g. general, spinal and local) and patient status at the end of anaesthesia.

Medical prostheses and blood products are two other classes. Medical prostheses includes data on the prostheses used for the patient, and blood products covers data on blood transfusions and use of blood products. Both these classes were included in an minimum data set for orthopaedic injuries (18). We propose a more comprehensive list of data elements for prostheses and blood classes compared with hospital information system document, the SEPAS system and hospital records.

Eleven data elements were proposed for the class of consultation, which covered data on specialized consultations with the patient. The data elements are 


\begin{tabular}{|c|c|}
\hline Data class & Data elements \\
\hline Diagnosis & $\begin{array}{l}\text { Main complaint, clinical finding data source, primary diagnosis, interim diagnosis, pre-operation } \\
\text { diagnosis, post-operation diagnosis, final diagnosis, pain scale, stroke scale, patient disability }\end{array}$ \\
\hline Pre-hospital emergency & $\begin{array}{l}\text { Mode of transport to emergency department, source of referral to emergency department (e.g. police), } \\
\text { vehicle dispatch to GPS location, accident/onset date/time, dispatch notified date/time }\end{array}$ \\
\hline Hospital emergency & $\begin{array}{l}\text { Type of emergency department visit, outcome of emergency department visit, patient problem } \\
\text { assessed in emergency department, outcome observation, date/time of patient entering the } \\
\text { emergency department, Glasgow coma scale }\end{array}$ \\
\hline Diagnostic/therapeutic procedure & $\begin{array}{l}\text { Procedure type (medical/diagnostic procedures), date/time of procedure, procedure name by ICD- } \\
9 \mathrm{CM} \text {, principal procedure code, start/end of operation, total time of operation }\end{array}$ \\
\hline Orders & $\begin{array}{l}\text { Order group, inpatient order, blood reserve order, consultations orders, laboratory tests orders, } \\
\text { radiography orders, order date/time }\end{array}$ \\
\hline Medical imaging & $\begin{array}{l}\text { Type of requested radiography, limb name, limb direction, technique, date of radiography, radiologist } \\
\text { notes, radiography result, authentication (signature or stamp) }\end{array}$ \\
\hline Laboratory & Test name, main group of test, test code, blood group, number, routine test \\
\hline Medicines & $\begin{array}{l}\text { Name of medications, medications code, types of medication, dosage strength, dose, type of } \\
\text { prescription (e.g. intravenous, intramuscular) }\end{array}$ \\
\hline Medical prosthetics & $\begin{array}{l}\text { Device name, device ID, model number, device purchase date, name of the requested instruments, } \\
\text { size, number for each, device serial number, code }\end{array}$ \\
\hline Blood products & $\begin{array}{l}\text { Blood request, blood type, blood group, date/time of start of injection, date/time of end of injection, } \\
\text { unit (e.g. } \mathrm{L} / \mathrm{mL} \text { ), blood pack serial number }\end{array}$ \\
\hline Discharge status & Revenue codes, discharge recommendations, discharge date, follow-up, places to visit for follow up \\
\hline Transfer & $\begin{array}{l}\text { Date/time patient departs, destination hospital, physician acceptance, cause of dispatch or transport, } \\
\text { diagnosis, arrival time, patient symptoms }\end{array}$ \\
\hline Follow up & $\begin{array}{l}\text { Referral practitioner name, referral organization, discharge medication order type, patient problem } \\
\text { assessed in follow up, follow up outcome observation, date/time of follow up }\end{array}$ \\
\hline System history and review & $\begin{array}{l}\text { Medical/surgical history, personal and family history, immunization history, environmental/food } \\
\text { allergies, alcohol/drug use indicators, data source }\end{array}$ \\
\hline Nursing & $\begin{array}{l}\text { Nursing report, date of report, time of report, considerations/observations of nurse, monitoring vital } \\
\text { signs, patient education, education topics }\end{array}$ \\
\hline Consultation & $\begin{array}{l}\text { Consultant practitioner ID, date/time consultation, date/time consultation starts, date/time } \\
\text { consultation stops, type of consultation, request a consultation to assess disease }\end{array}$ \\
\hline Death & $\begin{array}{l}\text { National code, sex, nationality, occupation, first/last name, newborn's mother, mother's national code, } \\
\text { mother's birth certificate number }\end{array}$ \\
\hline Anaesthesia & $\begin{array}{l}\text { Anaesthetics, supportive therapy (e.g. fluids, oxygen), anaesthesia start time, anaesthesia completion } \\
\text { time, type of anaesthesia, date of anaesthesia }\end{array}$ \\
\hline
\end{tabular}

GPS: global positioning system.

similar to the data elements of consultation request forms used in the Islamic Republic of Iran.

Eight data elements are suggested for the class of follow-up data. A number of Iranian studies have also used follow-up data $(2,18,19)$.

Although there is a class for discharge data in the administrative section, a separate class is included in the clinical section to record the clinical status of the patient on discharge. The focus of these data elements is on medical recommendations for treatment follow up at the time of discharge.

Problems in completing death certificates have been reported in the Islamic Republic of Iran $(40,41)$. Therefore, the data elements in the class of death include the data available in the certificate of death beyond seven days, stillbirth certificate and death certificate for children aged 0-6 days. We tried to organize the data elements of this class in accordance with World Health Organization and international death certificates (17).

The last class of the clinical section was transfer which deals with data of patient transfer between health centres, especially hospitals.

\section{Conclusion}

We evaluated the data sets of other countries, medical forms used in Iranian health centres, the SEPAS system, and hospital information system companies (although some hospital information system companies submitted incomplete data elements, which caused some limitations in the study), and the views of experts in the Ministry of Health and Medical Education, and propose 27 classes for the administrative and clinical data. Comparison of the data elements proposed in each class with similar studies showed that our suggested data set is 
more comprehensive and could help hospitals and other health care centres to record and report health data efficiently. Incorporation of the data elements proposed in our study into other specialized data sets developed for the Islamic Republic of Iran may be useful to develop an expanded national health data set. Moreover, our dataset can be used by the Ministry of Health and Medical Education, hospital information system companies and health surveillance centres for more efficient management of health data.

\section{Acknowledgements}

This study was a national project supported by Ministry of Health and approved in Kashan University of Medical Sciences (grant No: 94113).

Funding: This study was funded by the Iranian Ministry of Health.

Competing interests: None declared.

\section{Mise au point d'un ensemble de données minimum au niveau national pour les systèmes d'information hospitaliers en République islamique d'Iran}

\section{Résumé}

Contexte : La collecte de données standardisées facilite la gestion de l'information sur les maladies et se traduit par une meilleure qualité des soins. La République islamique d'Iran ne dispose pas d'un ensemble de données standard permettant de collecter des données dans les hôpitaux.

Objectifs : La présente étude avait pour objectif de mettre au point un ensemble de données minimum destiné aux systèmes d'information hospitaliers en République islamique d'Iran.

Méthodes : L'étude a été menée en 2015. Les ensembles de données issus d'autres pays, de dossiers hospitaliers, de systèmes d'information hospitaliers et de systèmes de dossiers médicaux électroniques disponibles en République islamique d'Iran ont été passés en revue afin de sélectionner les éléments à inclure dans l'ensemble de données minimum. Les éléments de données ont été collectés à l'aide d'un formulaire d'extraction, puis classés dans des catégories similaires, elles-mêmes divisées en sections administrative et clinique. La liste des éléments de données a été revue par les experts des services techniques du ministère iranien de la Santé et de l'Enseignement médical, et un ensemble de données minimum a été défini.

Résultats : Les sections administrative et clinique comportaient neuf et dix-huit catégories de données, avec un total de 166 et de 684 éléments de données respectivement. Suite à un examen par un groupe d'experts, 159 éléments de données administratives et 621 pour la partie clinique ont été retenus pour constituer l'ensemble de données minimum destiné au système d'information hospitalier iranien.

Conclusion : Cet ensemble de données peut être utilisé par le ministère susmentionné, les sociétés en charge des systèmes d'information hospitaliers et les centres de surveillance de la santé pour parvenir à une gestion plus efficace des données sanitaires.

$$
\begin{aligned}
& \text { تصميم مجموعة دنيا من البيانات الوطنية لنظم معلومات المستشفيات في جمهورية إيران الإسلامية } \\
& \text { زهرا رام ييشه، محمد اسماعيل كاملى، جو اد زارعى، اكرم واحدى برزكى، مرضيه معر اجى، على محمدى } \\
& \text { الخالاصة زمرام }
\end{aligned}
$$

الخلفية: يدعم جمع البيانات القياسية إدارة معلومات الأمراض ويؤدي إلى رفع مستوى جودة الرعاية. ولا تتو افر للى جمهورية إيران الإسلامية

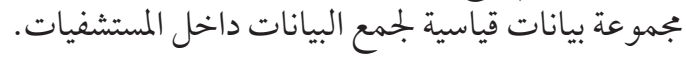
الأهداف: هدفت هذه الدراسة إلى تصميم بجموعة دنيا من البيانات لتشغيل نظم معلومات المستشفيات في جمهورية إيران الإسلامية.

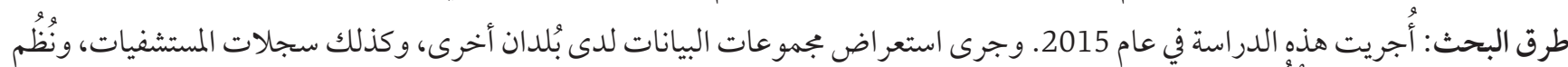

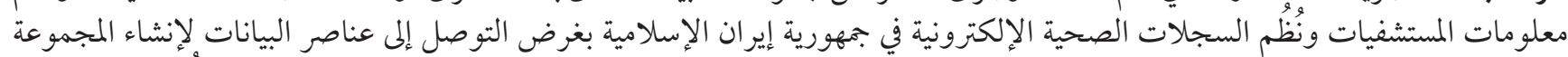

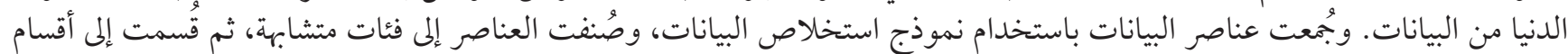

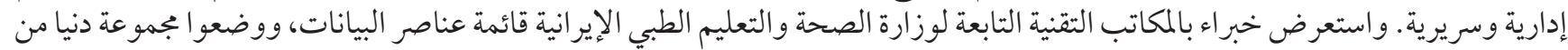

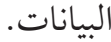

النتائج: كان هناك 9 و 18 فئة بيانات في كل من القسمين الإداري و السريري، بمجموع 166 و 684 عنصر بيانات، على التوالي. وبعد انتهاء فريق

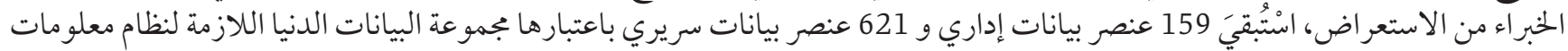

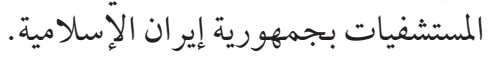


الاستنتاج: يمكن لوز زارة الصحة الإيرانية وشركات نُظمّم معلومات المستشفيات ومر اكز الترصُّد الصحي استخدام بجموعة البيانات الناشئة عن هذه الدراسة من أجل زيادة كفاءة إدارة البيانات الصحية. لصنية.

\section{References}

1. Mohammed SA, Yusof MM. Towards an evaluation framework for information quality management (IQM) practices for health information systems - evaluation criteria for effective IQM practices. J Eval Clin Pract. 2013;19(2):379-87. https://doi.org/10.1111/ j.1365-2753.2012.01839.x

2. Karimi S, Saghaeiannejad IS, Farzandipour M, Esmaeili Ghayoumabadi M. [Comparative study of minimum data sets of health information management of organ transplantation in selected countries and presenting appropriate solution for Iran]. Health Information Management. 2011;7(Special Issue):497-505. (In Farsi)

3. Hosseini A, Moghaddasi H, Jahanbakhsh M. [Designing minimum data sets of diabetes mellitus: basis of effectiveness indicators of diabetes management]. Health Information Management. 2010;7(3):330-40. (In Farsi)

4. Abdelhak M, Grostick S, Hanken MA, Ellen J. Health information: management of a strategic resource. Fourth edition. Philadelphia: Elsevier - Health Sciences Division; 2012.

5. Cai S, Mukamel DB, Veazie P, Temkin-Greener H. Validation of the Minimum Data Set in identifying hospitalization events and payment source. J Am Med Dir Assoc. 2011;12(1):38-43. https://doi.org/10.1016/j.jamda.2010.02.001

6. Kowal PR, Wolfson LJ, Dowd JE. Creating a minimum data set on ageing in sub-Saharan Africa. S Afr J Gerontol. 2000;9:18-23.

7. Ghaneie M, Rezaie A, Ghorbani N, Heidari R, Arjomandi M, Zare M. Designing a minimum data set for breast cancer: a starting point for breast cancer registration in Iran. Iran J Public Health. 2013;42(Suppl 1):66-73.

8. Sadoughi F, Ghazisaeidi M, Mehraji M, Kimiafar Kh, Ramezanghorbani N. [Health Information management technology]. Tehran: Jafari Publication; 2011. (In Farsi)

9. Bloemhoff A, Hoyinck S, Dekker R, Mulder S. Development of minimum data sets on injuries: background report. Amsterdam: Consumer Safety Institute; 2001.

10. Qatar patient minimum data set (MDS). Doha: Supreme Council of Health; 2015 (SCH/HFID/MDS/V4 2015).

11. Victorian emergency minimum dataset (VEMD). Melbourne: Department of Health \& Human Services; 2012.

12. Emergency health services - patient care reporting minimum data set. Alberta: Health Information Standards Committee for Alberta; 2011.

13. National Health Board. National minimum dataset (NMDS) - hospital events. Data dictionary. Wellington: Ministry of Health; 2014.

14. Preliminary recommendations for core health data elements 1996. Hyattsville: National Committee on Vital and Health Statistics; 1996 (https://www.cdc.gov/nchs/data/ncvhs/nchvs94.pdf, accessed 25 September 2017).

15. Davis N, LaCour M. Health information technology. Third edition. St Louis: Elsevier; 2014.

16. Wager KA, Lee FW, Glaser JP. Managing a health care information systems: a practical approach for health care executives. San Francisco: John Wiley \& Sons; 2005.

17. International statistical classification of diseases and related health problems, 1oth revision. Geneva: World Health Organization; 2011.

18. Ahmadi M, Mohammadi A, Chraghbaigi R, Fathi T, Baghini MS. Developing a minimum data set of the information management system for orthopedic injuries in Iran. Iran Red Crescent Med J. 2014;16(7):e17020. https://doi.org/10.5812/ircmj.17020

19. Ahmadi M, Alipour J, Mohammadi A, Khorami F. Development a minimum data set of the information management system for burns. Burns. 2015;41(5):1092-9. https://doi.org/10.1016/j.burns.2014.12.009

20. Zhan C, Miller M. Administrative data based patient safety research: a critical review. Qual Saf Health Care. 2003;12(Suppl 2):ii58ii63. https://doi.org/10.1136/qhc.12.suppl_2.ii58

21. Ahmadi M, Bashiri A. [A minimum data set of radiology reporting system for exchanging with electronic health record system in Iran.] J Payavard Salamat. 2014;8(2):121-33. (In Farsi)

22. Arastoo AA, Nickbakht M, Ghasemzadeh R, Azizi A, Zahednejad S, Latifi SM. Developing a national minimum data set for physiotherapy in Iran: a Delphi study. Eur J Sci Res. 2013;107(4):573-9.

23. Kalankesh LR, Dastgiri S, Rafeey M, Rasouli N, Vahedi L. Minimum data set for cystic fibrosis registry: a case study in Iran. Acta Inform Med. 2015;23(1):18-21. https://doi.org/10.5455/aim.2015.23.18-21

24. Disability Services National Minimum Data Set: data guide, July 2016. Canberra: Australian Institute of Health and Welfare; 2016 (https://www.aihw.gov.au/getmedia/1026f6oa-cc97-40fb-a6ef-46c25ec006a6/ds-nmds-data-guide-2016-17.pdf.aspx , accessed 3 October 2019).

25. Pollock DA, Adams DL, Bernardo LM, Bradley V, Brandt MD, Davis TE, et al. Data elements for emergency department systems, Release 1.o (DEEDS): a summary report. J Emerg Nurs. 1998;24(1):35-44. 
26. Long-term care facility resident assessment. Instrument 3.o. User's Manual, version 1.13. Baltimore: Centers for Medicare \& Medicaid Services; 2015.

27. Admitted patient care NMDS 2016-17. Canberra: Australian Institute of Health and Welfare; 2017 https://meteor.aihw.gov.au/ content/index.phtml/itemId/612171, accessed 3 August 2019).

28. International classification of external causes of injuries (ICECI) version 1.2. Amsterdam: Consumer Safety Institute and Adelaide: AIHW National Injury Surveillance Unit; 2004.

29. Injury surveillance. National minimum data set. National health data dictionary, version 12. Canberra: Australian Institute of Health and Welfare; 2003.

30. Mohammadi A, Ahmadi M, Gharagozlu A. Developing a minimum data set for an information management system to study traffic accidents in Iran. Iran Red Crescent Med J. 2016;18(3):e23677. https://doi.org/10.5812/ircmj.23677

31. IDB-JAMIE minimum data set (IDB-MDS). Data dictionary. Netherlands: European Association for Injury Prevention and Safety Promotion Office. 2013.

32. Ghaffari Sh, Abolhallaj M, Pouragha B. [Feasibility of implementing diagnosis related groups: a case study in Iran's hospitals.] Hakim. 2012;15(2):147-57. (In Farsi)

33. Safdari R, Shahmoradi L, Ebrahimi M. [Minimum data set of anatomical pathology information system from the perspective of experts. J Payavard Salamat.] 2015;9(3):300-14. (In Farsi)

34. Zhan FB, Lu Y, Giordano A, Hanford EJ. Geographic information system (GIS) as a tool for disease surveillance and environmental health research. In: Proceedings of ICSSSM'05. 2005 International Conference on Services Systems and Services Management, Vol. 2. IEEE; 2005:1465-70.

35. Salarvand Sh, Sheikh Abumasoudi R, Kashani F, Samadbeik M, Salarvand H. [Assessing the necessitate quality indicators of hospitals' websites (a literature review)]. Hospital. 2016;15(1):87-100. (In Farsi)

36. Moghaddasi H, Rabiei R, Mastaneh Z. [Pre-hospital emergency information system in America and England: a review.] Payesh. 2014;13(4):383-91. (In Farsi)

37. Jangi M, Azizi A, Kamali Yousef Abad M, Tara SM. [Systematic design of the minimum data set storage: an essential need to create purposed for archiving]. J Health Biomedical Informatics. 2015;1(2):113-21. (In Farsi)

38. Safdari R, Dargahi H, Halabchi F, Shadanfar K, Abdolkhani R. [A comparative study of the athlete health records' minimum data set in selected countries and presenting a model for Iran.] J Payavard Salamat. 2015;8(2):134-45. (In Farsi)

39. Rafii F, Ahmadi M, Hoseini A. [Nursing minimum data set: an essential need for Iranian health care system.] Iran Journal of Nursing. 2011;24(71):19-27. (In Farsi)

40. Meraji M, Barabadi M. [Errors in the documentation of the death certificate: a case study.] J Health Biomed Informatics. 2015;2(3):168-75. (In Farsi)

41. Keyvanara M, Zardoeigolanbar S, Karimi S, Isfahani SS. [The quality of death certificates record in the educational and non-educational hospitals in Kermanshah, Iran]. Health Information Management. 2011;8:23-32. (In Farsi) 